\title{
Horizontal and Vertical Distribution and Abundance of Zooplankton around the Swatch-of-No-Ground of Northern Bay of Bengal
}

\author{
Nurany Sadia ${ }^{1}$, Md Kawser Ahmed ${ }^{1,2}$, Md. Moniruzzaman Khondkar ${ }^{3}$, Seema Rani ${ }^{2}$, Md. Jobaer \\ Alam $^{1}$, Ahmad Al Karim ${ }^{4}$ and Makidul Islam Khan ${ }^{2}$ \\ ${ }^{1}$ Department of Oceanography, University of Dhaka, Dhaka-1000, Bangladesh \\ ${ }^{2}$ International Centre for Ocean Governance (ICOG), University of Dhaka, Dhaka-1000, Bangladesh \\ ${ }^{3}$ Department of Botany, University of Dhaka, Dhaka-1000, Bangladesh \\ ${ }^{4}$ Maritime Affairs Unit (MAU), Ministry of Foreign Affairs, Segunbagicha, Dhaka, Bangladesh
}

Manuscript received: 15 August 2021; accepted for publication: 22 November 2021

\begin{abstract}
This study assessed horizontal and vertical distribution and abundance of zooplankton community in water samples collected from 26 stations at a depth of 0 to $250 \mathrm{~m}$ of the northern Bay of Bengal. A total of 55 zooplankton species were identified where Copepod was $72.41 \%$ and Ciliophora was $8.62 \%$. Among the Copepod, $48 \%, 40 \%$ and $12 \%$ of species were Calanoid, Cyclopoid and Harpacticoid Copepod, respectively. This study also found 2 species of Decapod, 2 species of Rotifer, 2 species of Cladocera, 1 species of Chaetognatha and 1 species of Stomatopoda. Spatial distribution of zooplankton species was varied from station to station and cruise to cruise. Maximum 23,868 individuals of zooplanktons were recorded in cruise 2, whereas the lowest number (758 individuals) was found in cruise 4 . Zooplankton abundance was ranged between 18 to 22,500 cells/L in all cruises, whereas the highest abundance was found in cruise 2 and the lowest was recorded in cruise 4 . The highest abundance $(37,310$ individuals) was documented at surface water and the lowermost number of zooplankton (10 individuals) was recorded at $100 \mathrm{~m}$ depth. This study showed negative correlation between zooplankton abundance and water depth. The results of the current study might help to understand zooplankton abundance and distribution in the northern Bay of Bengal and will use as a baseline study for further research.
\end{abstract}

Keywords: Zooplankton biomass, Distribution pattern, Vertical assemblages, Copepods, Northern Bay of Bengal

\section{INTRODUCTION}

Zooplankton is considered as a diverse composition of faunas that might drift or actually transport in the waters in the global oceans. They transfer biological energy formed by phytoplankton to higher trophic levels as the synchrony between predator and prey (match-mismatch) and in the effective recruitment of the top predators such as fish and sea birds (Christoffersen et al., 1993; D'Alelio et al., 2016; Durant et al., 2019). Thus, the zooplankton plays a central role in the pelagic food web by governing primary production and determining pelagic environment (Kiørboe, 1997). Spatio-temporal distribution, abundance and diversity of zooplankton is a vital indicator in shaping the fish stock. Therefore, any change or alteration in zooplankton community might impact on ecosystem functioning.

Corresponding author: Nurany Sadia

Email: nurany.sadia@gmail.com

DOI: https://doi.org/10.3329/dujees.v10i2.57510
Zooplankton distribution, abundance and diversity is mostly controlled by diverse environmental parameters since zooplanktons are mildly carried in the surface layer of the sea by ocean currents. A slight fluctuation in ambient water parameters could seriously alter zooplankton community that can change larval survival and ultimately fish production (Greenwood et al., 2001). The abundance of zooplankton relies on the availability of nutrients in the water column and abundance of other plankton (Srichandan et al., 2013). Periodic plankton succession is mostly delimited by salinity fluctuations and temperature changes (Lawrence et al., 2004; Antoni et al., 2020). Thus, prey availability and predation, competition and feeding preference play a significant role in zooplankton assemblage changes (Sailley et al., 2015).

Zooplankton's vertical movement depends on both biotic and abiotic factors (Nowicki et al., 2017; Bandara et al., 2021). Zooplankton's displacement from the upper layer of water to deeper waters depends on food availability and predation since rate of predation is higher in lighted upper ocean waters at 
daytime. At night, zooplankton will shift back to surface layer of the ocean to feed on phytoplankton. The shift of zooplankton species from a zone of high food availability to one of limited food accessibility, where limited temperatures and oxygen diminish respiration and help to conserve energy that stimuli zooplankton movement along the water column (Bandara et al., 2021).

The Bay of Bengal, on the south-eastern coast of Bangladesh, is an untapped blue resource that has great potential to contribute to national economy. A massive volume of freshwater is discharged in the northern Bay of Bengal via the Ganges-BrahmaputraMeghna delta and others and as a result, salinity and temperature fluctuations might play a key role in determining the zooplankton distribution and diversity in the Bay of Bengal. In addition, tropical monsoonal climate might also alter phytoplankton distribution and abundance in the Bay of Bengal and ultimately influence zooplankton distribution and abundance. A few studies were conducted to assess zooplankton distribution and abundance in the Bay of Bengal of Indian part (e.g., Fernandes and Ramaiah, 2009; Rakhesh et al., 2006; Baliarsingh et al., 2018; etc.). However, there is scarce studies in the northern Bay of Bengal. Though a few studies were conducted to assess zooplankton distribution and abundance in coastal and mangroves areas of Bangladesh (e.g., Hena et al., 2016; Sharif et al., 2017; Abdullah-Al et al., 2018; Abdullah-Al et al., 2020 ; etc.), those studies were different from the abundance and distribution of zooplankton in the northern Bay of Bengal. That is why, this study aimed to identify marine zooplankton species from the water samples in the northern Bay of Bengal and assess their horizontal and vertical distribution and abundance to offer a comprehensive understanding of the zooplankton communities of the northern Bay of Bengal.

\section{MATERIALS AND METHODS}

\section{Study area}

In the present study, samples were collected from a total of 26 stations (Figure 1) during four cruises in the northern Bay of Bengal, Bangladesh. Details of sampling such as sampling position, number of horizontal and vertical sampling stations that covered in each cruise and vertical sampling depths are showed in Table 1.

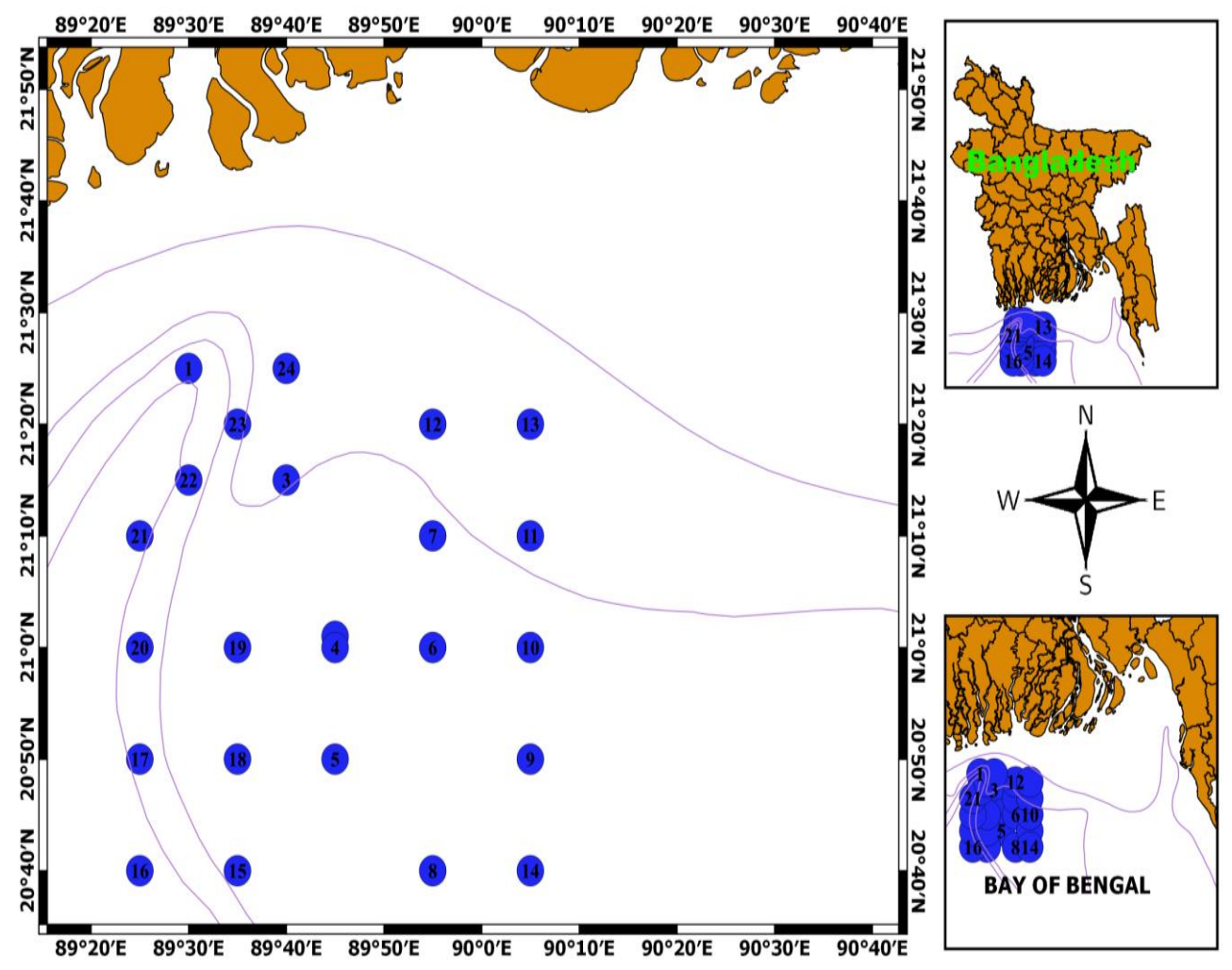

Figure 1: Sampling Stations in the Northern Bay of Bengal, Bangladesh 
Table 1: Sample Collection Details for Four Cruises that were held in the Northern Bay of Bengal

\begin{tabular}{|c|c|c|c|c|}
\hline Cruise name & $\begin{array}{l}\text { Cruise } 1 \text { (BNS } \\
\text { Karotoa) }\end{array}$ & Cruise 2 (BNS Turag) & Cruise 3 (BNS Kapotakkho) & Cruise 4 (BNS Turag) \\
\hline Cruise time & $\begin{array}{l}\text { 26.01.2017- } \\
28.01 .2017\end{array}$ & $\begin{array}{l}12.02 .2017- \\
16.02 .2017\end{array}$ & 21.02.2017-27.02.2017 & $\begin{array}{l}30.12 .2017- \\
02.01 .2018\end{array}$ \\
\hline Sampling position & $\begin{array}{l}20.80-21.50 \mathrm{~N} \\
89.37-90.08 \mathrm{E}\end{array}$ & $\begin{array}{l}20.08-21.85 \mathrm{~N} \\
89.05-90.01 \mathrm{E}\end{array}$ & $\begin{array}{l}20.05-21.42 \mathrm{~N} \\
89.05-90.08 \mathrm{E}\end{array}$ & $\begin{array}{l}20.00-21.42 \mathrm{~N} \\
89.05-89.92 \mathrm{E}\end{array}$ \\
\hline $\begin{array}{l}\text { Surface sampling } \\
\text { station no. }\end{array}$ & $10(10)$ & $21(21)$ & $13(13)$ & $20(20)$ \\
\hline $\begin{array}{l}\text { Vertical sampling } \\
\text { station no. }\end{array}$ & $10(12)$ & $20(55)$ & $24(47)$ & $26(53)$ \\
\hline $\begin{array}{l}\text { Sample collection } \\
\text { depth }(\mathrm{m})\end{array}$ & $\begin{array}{l}\text { Surface, 5(4), } \\
10(3), 15(2), \\
50(1), 90(2)\end{array}$ & $\begin{array}{l}\text { Surface, 5(12), 10(6), } \\
15(13), 20(1), 30(2), \\
45(1), 50(10), 80(2), \\
85(1), 90(7)\end{array}$ & $\begin{array}{l}\text { Surface, 5(4), 10(2), 15(6), } \\
20(3), 25(1), 30(5), 40(5), \\
50(7), 70(2), 80(3), 90(6), \\
150(2), 250(1)\end{array}$ & $\begin{array}{l}\text { Surface, 5(3), 10(21), } \\
15(2), 25(2), 50(18), \\
100(5), 150(1), 200(1)\end{array}$ \\
\hline
\end{tabular}

*Numerical values in parenthesis represents sampling frequency on how many times samples were collected from different stations at a similar depth.

\section{Zooplankton sampling}

\section{Collection of surface sample}

Surface samples were collected using a Bongo net (diameter: $50 \mathrm{~cm}$ and mesh size: $60 \mu \mathrm{m}$ ) and collected samples were stored in $500 \mathrm{ml}$ plastic bottle.

\section{Horizontal sampling}

Plankton net (diameter in $50 \mathrm{~cm}$ and mesh size 60 $\mu \mathrm{m})$ was towed horizontally for 3 minutes at each station to collect zooplankton sample and the samples were stored in a $250 \mathrm{ml}$ bottle. These samples were preserved in $5 \%$ formalin solution.

\section{Vertical sampling}

Samples were collected by Niskin water sampler (8 L capacities) at different depth depending on water column's depth to assess vertical zooplankton distribution. After samples collection, it was filtered through plankton net (mesh size: $60 \mu$ ) and the samples were stored in a $250 \mathrm{ml}$ bottle.

\section{Preservation of sample}

After sample collection, all samples were tagged carefully, and sampling details were written down in each tag. Using plastic dropper, 5\% formalin solution was added in each sample containing bottle and was shaken gently to mix properly. The samples color remained unchanged. At the end, all sample bottles were kept at Chemical Oceanography Laboratory of Oceanography Department, University of Dhaka for identification of the zooplankton samples.

\section{Identification and counting of zooplankton sample}

Biological microscope (Motic- TO.25 A) was used to observe and identify zooplankton species following the methods of Davis (1995), Thomas (1997) and Khondker (2008). Photographs of identified species were taken using a digital camera at a magnification of $10 \times 10 \mathrm{X}$. To count zooplankton's number, $1 \mathrm{ml}$ of concentrated sample was placed on the grids of Sedgewick-Rafter cell (model-1801-G20, manufactured by Wildlife Supply Company, USA and model S50, manufactured by Graticules Ltd., Maryland Road, England) and counted.

\section{Data analysis}

Microsoft Excel (version-13) was used to analyze the data. Mostly descriptive statistics were used in this study and findings were represented in tabular and graphical forms.

\section{RESULTS AND DISCUSSION}

\section{Zooplankton identification}

In this study, total 55 zooplankton species were identified from the water samples of northern Bay of Bengal (Figure 2). Majority of the zooplankton species were Copepod (72.41\%) followed by Ciliophora (8.62\%). Among the Copepod, 48\%, $40 \%$ and $12 \%$ of species were Calanoid, Cyclopoid and Harpacticoid Copepod, respectively (Figure 3). This study also found 2 species of Decapod, 2 species of Rotifer, 2 species of Cladocera, 1 species of Chaetognatha and 1 species of Stomatopoda. 


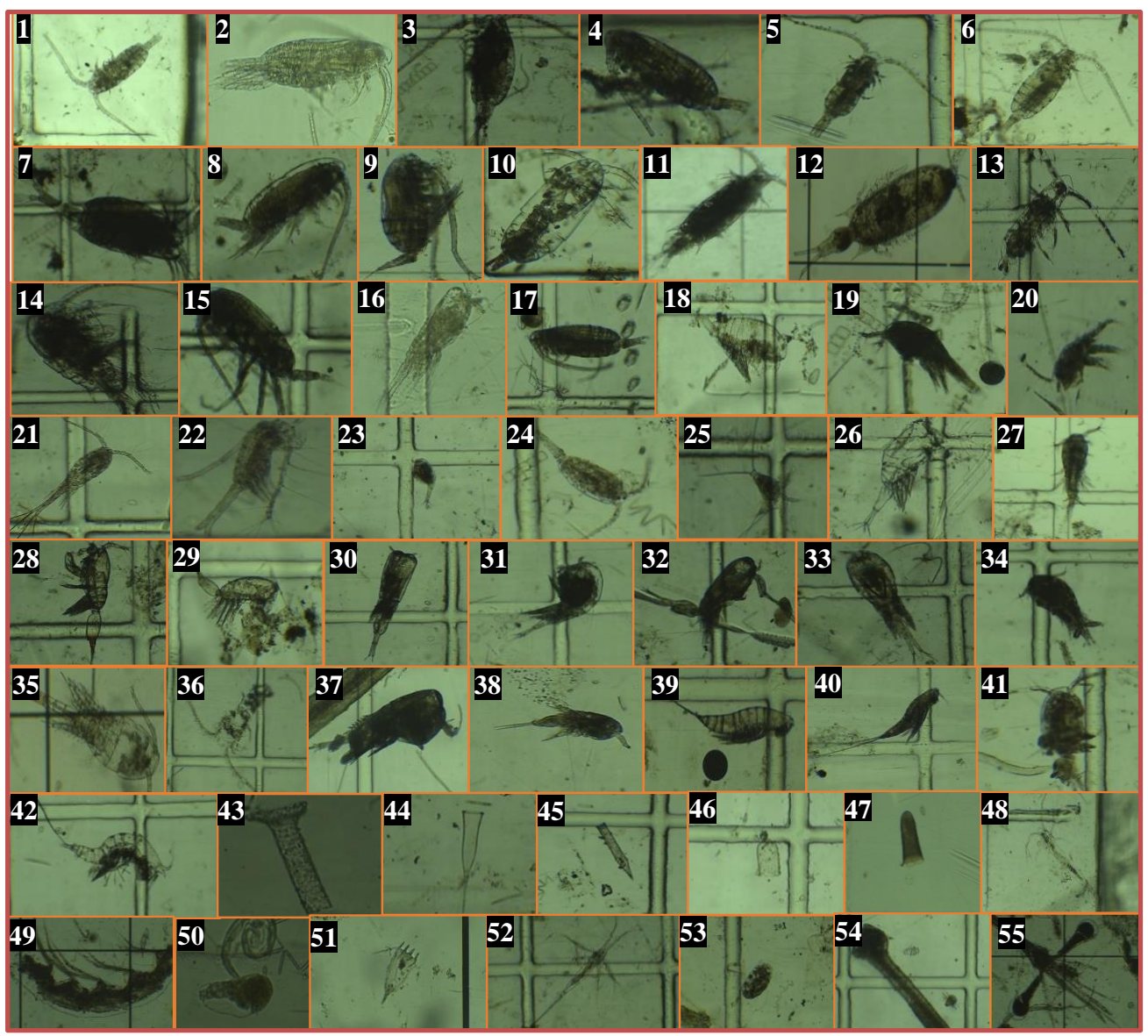

Figure 2: Photographs of Identified Zooplankton Species in Copepod (1-42): Calanoida (1-20): 1. Acartia negligen, 2. A. bifilosa, 3. Paracalanus parvus, 4. P. pacificus, 5. Paraeuchaeta norvegica, 6. P. Barbara, 7. Calanopia elliptica, 8. Calanus pacificus, 9. Clausocalanus arcuicornis, 10. C. furcatus, 11. Centropages furcatus, 12. Labidocera trispinosa, 13. Leptodiaptomus minutus, 14. Candacia armata, 15. Metridia lucens, 16. M. longa, 17. Metridia sp., 18. Microcalanus pusillus, 19. Temora longicornis and 20. Euchaeta concinna; Cyclopoida (21-37): 21. Oithona plumifera, 22. O. similis, 23. O. ocuata, 24. O. brevicornis, 25. O. helgolandica (nauplius), 26. Oncaea mediterranea, 27. O. rosea, 28. O. venusta, 29 . O. clavei, 30. Corycaeus flaccus, 31. C. pacificus, 32. C. specious, 33. Cyclops strenuous, 34. C. abyssorum, 35. Cyclops sp., 36. Ergasilus sp. and 37. Farranula gibbula; and Harpacticoida (38-42): 38. Attheyella sp., 39. Microsetella norvegica, 40. M. rosea 41. Tigriopus japonicas and 42. Euterpina acutifrons; Ciliophora (43-47): Choreotrichida (43-44): 43. Leprotintinnus sp. and 44. Helicostomella sp.; Oligotrichida (45-46): 45. Tintinniopsis radicand and 46. Favella sp.; and Tintinnida: 47. Codonella cratera; Decapoda (48-49): 48. Gennadas elegans and 49. Lucifer faxoni; Rotifer (50-51): 50. Collotheca ornate and 51. Keratella cochlearis; Cladocera (52-53): 52. Leptodora kindtii and 53. Evadne sp.; Chaetognatha: 54. Chaetognatha sp. and Stomatopoda: 55. Stomatopoda sp.

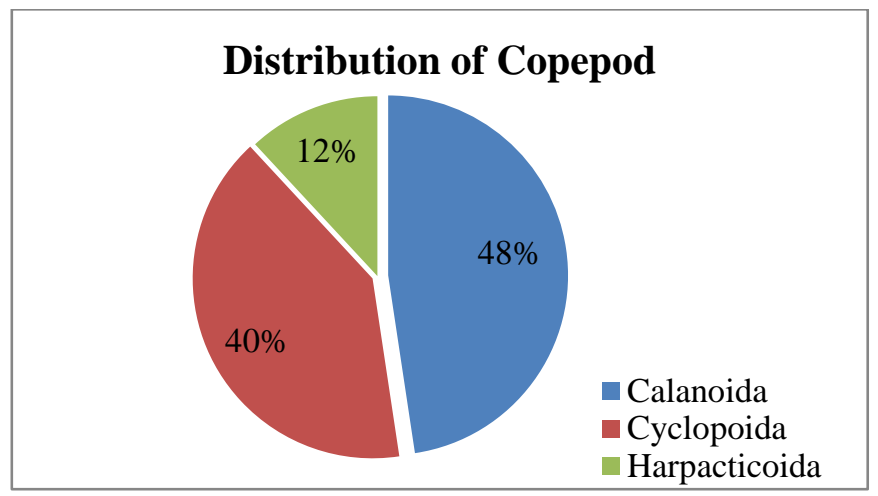

Figure 3: Distribution of Copepod Species in Water Samples Collected from Northern Bay of Bengal 
The identified zooplankton species in this study was higher than the identified number of zooplankton in the north-eastern Bay of Bengal by Islam and Aziz (1975) who recorded 18 marine zooplankton species. Abdullah-Al et al. (2020) identified 38 zooplankton species in coastal waters of the northern Bay of Bengal that was lower than the identified number of species in this study. In coastal water of Sundarbans mangrove forest, Mamun et al. (2009) recorded 11 genera of zooplankton species that was comparatively much lower than the present study. Srichandan et al. (2013) reported 86 species of zooplankton in Odisha estuary of India. However, Fernandes and Ramaiah (2009) recorded 163 species under 27 taxonomic group where dominated order was Calanoid Copepods during an expedition in the Bay of Bengal, India that was much higher than the results of the present study which might be occurred due to seasonal variation. Fernandes and Ramaiah (2009) assessed the spatial variability of mesozooplankton biomass and composition during summer monsoon season, whereas this study was conducted in winter season. Jitlang et al. (2007) also recorded 205 species under 119 genera of zooplankton community in the Bay of Bengal. Jitlang et al. (2007) showed a very high number of zooplankton species than the present study which might be occurred because of 3 times higher sampling days and differences in geographical areas to collect water samples from the Bay of Bengal.

\section{Spatial distribution and abundance of zooplankton}

This study found that spatial distribution of zooplankton individuals was varied from station to station and cruise to cruise. The highest number (23,868 individuals) of zooplankton was recorded in cruise 2 when maximum 21 stations were covered to collect water samples from the northern Bay of Bengal (Table 2). In contrast, the lowest abundance (758 individuals) found in cruise 4. Zooplankton abundance was ranged from 18 to 22,500 cells/ $\mathrm{L}$ in all cruises, whereas the highest abundance was found in cruise 2 and the lowest in cruise 4 . Baliarsingh et al. (2018) found 2,098 individuals/L and 833 individuals $/ \mathrm{L}$ in coastal waters of the north-western Bay of Bengal away from $0-20 \mathrm{~m}$ and $30-50 \mathrm{~m}$ from the shorelines respectively. Rakhesh et al. (2006) found 10,369, 2,810 and 240 individuals/L for coastal, shelf and oceanic waters in the northeast coast of India, Bay of Bengal, and concluded that zooplankton abundance in neritic and oceanic waters was varied depending on distance from the coastline.

Table 2: Zooplankton Abundance in Surface Water Collected from the Northern Bay of Bengal During Different Cruises

\begin{tabular}{lllll}
\hline Cruise name & Cruise date & Station number & Number of individuals & Zooplankton abundance (cells/L) \\
\hline $\begin{array}{l}\text { Cruise 1 } \\
\text { (BNS Karotoa) }\end{array}$ & $\begin{array}{l}26.01 .2017- \\
28.01 .2017\end{array}$ & 10 & 11,066 & $15-10,000$ \\
\hline $\begin{array}{l}\text { Cruise 2 } \\
\text { (BNS Turag) }\end{array}$ & $\begin{array}{l}12.02 .2017- \\
16.02 .2017\end{array}$ & 21 & 23,868 & $25-22,500$ \\
\hline $\begin{array}{l}\text { Cruise 3 } \\
\text { (BNS Kapotakkho) }\end{array}$ & $\begin{array}{l}21.02 .2017- \\
27.02 .2017\end{array}$ & 13 & 1,618 & $25-555$ \\
\hline $\begin{array}{l}\text { Cruise 4 } \\
\text { (BNS Turag) }\end{array}$ & $\begin{array}{l}30.12 .2017- \\
02.01 .2018\end{array}$ & 20 & 758 & $18-83$ \\
\hline
\end{tabular}

\section{Vertical distribution and abundance of zooplankton}

This study showed that vertical distribution of zooplankton individuals was differed based on changes of water depth. The highest abundance (37,310 individuals) was observed at surface water and the abundance was lessened as the water depth increases (Figure 4). The lowest number of zooplankton (10 individuals) was recorded at $100 \mathrm{~m}$ depth. Though water samples were collected from 250 $\mathrm{m}$ depth in this study, no zooplankton was recorded in that depth.

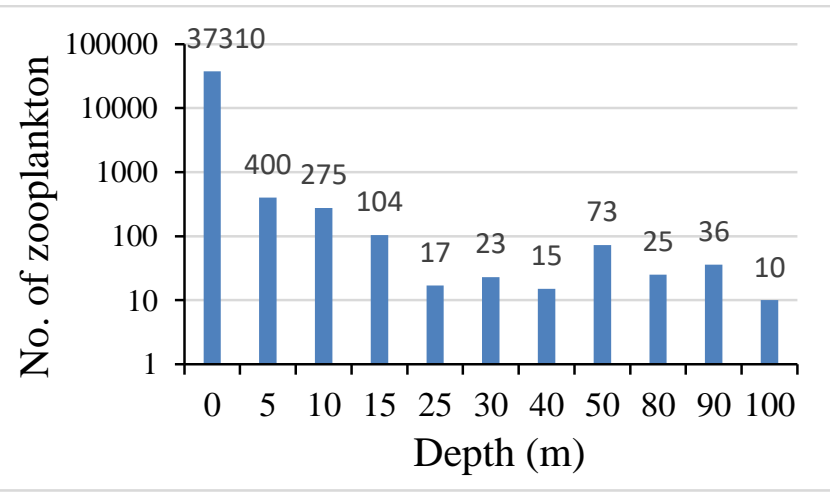

Figure 4: Vertical distribution of zooplankton individuals in the northern Bay of Bengal, Bangladesh 
Table 3 and 4 showed the summary of vertical distribution of zooplankton individuals in four cruises. The findings of this study were in line with Nandini et al. (2008) who also reported negative relationship between zooplankton abundance and water depth in Valle de Bravo, Mexico. This might be correlated with changing water temperature and food availability at higher depth.

Table 3: Vertical Distribution of Zooplankton Individuals in the Northern Bay of Bengal, Bangladesh

\begin{tabular}{lllll}
\hline $\begin{array}{l}\text { Depth } \\
(\mathrm{m})\end{array}$ & $\begin{array}{l}1^{\text {st }} \text { Cruise }(26.01 .2017- \\
28.01 .17)\end{array}$ & $\begin{array}{l}2^{\text {nd }} \text { Cruise } \\
(12.02 .2017-16.02 .2017)\end{array}$ & $\begin{array}{l}3^{\text {rd }} \text { Cruise } \\
(21.02 .2017-27.01 .17)\end{array}$ & $\begin{array}{l}4^{\text {th }} \text { Cruise } \\
(30.12 .2017-02.01 .18)\end{array}$ \\
\hline Surface & 11,066 & 23,868 & 1,618 & 758 \\
\hline 5 & 67 & 221 & 44 & 68 \\
\hline 10 & 36 & 43 & 33 & 163 \\
\hline 15 & 8 & 63 & 8 & 25 \\
\hline 25 & & & 17 \\
\hline 30 & & 23 & \\
\hline 40 & & 15 & 34 \\
\hline 50 & 23 & 5 & 11 & \\
\hline 80 & & 25 & 10 \\
\hline 90 & 36 & &
\end{tabular}

Table 4: Distribution of Zooplankton at Different Depth (m) of Water Column Collected from Northern Bay of Bengal

\begin{tabular}{|c|c|c|c|c|}
\hline $\begin{array}{l}\text { Cruise name } \\
\text { and date }\end{array}$ & $\begin{array}{l}1^{\text {st }} \text { Cruise } \\
(26.01 .2017-28.01 .17)\end{array}$ & $\begin{array}{l}2^{\text {nd }} \text { Cruise } \\
(12.02 .2017-16.02 .2017)\end{array}$ & $\begin{array}{l}3^{\text {rd }} \text { Cruise } \\
(21.02 .2017-27.01 .17)\end{array}$ & $\begin{array}{l}4^{\text {th }} \text { Cruise } \\
(30.12 .2017-02.01 .18)\end{array}$ \\
\hline 5 & $18(2), 8(1), 23(1)$ & $\begin{array}{l}8(1), 18(3), 23(3), 25(1), \\
30(1), 35(1),-(2)\end{array}$ & $8(2), 10(1), 18(1)$ & $18(1), 25(2)$ \\
\hline 10 & $8(1), 10(1) 18(1)$ & $10(1), 13(1), 20(1),-(3)$ & $15(1), 18(1)$ & $\begin{array}{l}3(5), 5(1), 8(3), 18(3), \\
20(2), 25(1),-(6)\end{array}$ \\
\hline 15 & $3(1), 5(1)$ & 13(1), 16(1), 34(1), -(10) & $8(1),-(5)$ & $10(1), 15(1)$ \\
\hline 20 & & $-(1)$ & $-(3)$ & \\
\hline 25 & & & $-(1)$ & $8(1), 9(1)$ \\
\hline 30 & & $-(2)$ & $5(1), 8(1), 10(1),-(2)$ & \\
\hline 40 & & & $15(1),-(4)$ & \\
\hline 45 & & $-(1)$ & & \\
\hline 50 & $23(1)$ & $5(1),-(9)$ & $3(2), 5(1),-(4)$ & $\begin{array}{l}3(1), 5(1), 8(1), 18(1), \\
-(14)\end{array}$ \\
\hline 70 & & & $-(2)$ & \\
\hline 80 & & $-(2)$ & $5(1), 20(1),-(1)$ & \\
\hline 85 & & $-(1)$ & & \\
\hline 90 & $-(2)$ & $8(1), 28(1),-(7)$ & $-(6)$ & \\
\hline 100 & & & & $5(2),-(3)$ \\
\hline 150 & & & $-(2)$ & $-(1)$ \\
\hline 200 & & & & $-(1)$ \\
\hline 250 & & & $-(1)$ & \\
\hline
\end{tabular}

*Numerical values in parenthesis represents sampling number on how many times same number of zooplankton individuals were observed from diverse stations at a similar depth and "--" indicates individual not found.

The distribution and abundance of zooplankton in northern to western Bay of Bengal, mostly relies on diverse environmental factors like changes in water flow, current action, tidal oscillation, and accessibility of nutrients (Rakhesh et al., 2006; Prabhahar et al., 2011; Srichandan et al., 2013). Moreover, zooplankton abundance and distribution might also be influenced by phytoplankton abundance and distribution (Rekhesh et al., 2006). Moreover, the nutrients deposited on the bottom by microbial functions are dispersed in the monsoon season because of up- and down-welling progressions that 
could alter the horizontal and vertical distribution and abundance of zooplankton in the oceans (Verheye and Hutchings, 1988; Ibáñez-Tejero et al., 2018). Thus, it is imperative to comprehend the abundance, distribution and diversity of zooplankton community as it draws a crucial contribution in the trophic linkage between primary production and predators e.g., aquatic organisms including fish and marine animals. Findings of this study might be served as a baseline study for further investigations to explore the distribution and diversity of zooplankton species in the northern Bay of Bengal.

\section{CONCLUSIONS}

This study assessed horizontal and vertical distribution and abundance of zooplankton community from the differed northern Bay of Bengal. This study reported that zooplankton abundance and distribution was from station to station and zooplankton abundance was inversely correlated with water depth which might be linked with seasonal changes, temperature alterations, salinity fluctuations or food availability, etc. The findings of this study might provide baseline data for future research works and will help to understand zooplankton horizontal and vertical distribution in the northern Bay of Bengal. This study suggests to correlate environmental parameters and zooplankton abundance and distribution to get comprehensive understanding about their biomass composition. Spatio-temporal analyses of zooplankton communities will help to explain seasonal differences of zooplankton distributions in the northern Bay of Bengal.

Acknowledgements: The authors would like to convey their sincere thanks to Bangladesh Navy for the required permission to get on board to collect the samples. The authors would also express their special appreciation to Lt. Commander Hasnain Anik, Bangladesh Navy, and Mr. Muhammad Shahinur Rahman and Mr. Rupak Loodh, Bangladesh Oceanographic Research Institute (BORI) to collect the samples during the cruises.

\section{REFERENCES}

Abdulah-Al, M., Akhtar, A., Rahman, M. F., Uddin, S. A., and Modeo, L. (2020). Temporal distribution of zooplankton communities in coastal waters of the northern Bay of Bengal, Bangladesh. Regional Studies in Marine Science, 34, 100993.
Abdullah-Al, M., Akhtar, A., Kamal, A. H. M., Islam, M. S., Uddin, M. M., Alam, M. D., \& Xu, H. (2018). Seasonal pattern of zooplankton communities and their environmental response in subtropical maritime channels systems in the Bay of Bengal, Bangladesh. Acta Ecologica Sinica, 38(4): 316-324.

Abu Hena, M. K., Siddik, B. J., Idris, M. H., Johan, I., Nesarul, N. H., Aysha, A., \& Islam, M. S. (2016). Seasonal distribution of zooplankton composition and abundance in a sub-tropical mangrove and salt marsh estuary. Malaysian Journal of Science, 35(2): 275-289.

Antoni, J. S., Almandoz, G. O., Ferrario, M. E., Hernando, M. P., Varela, D. E., Rozema, P. D., Buma, A. G., Paparazzo, F. E., \& Schloss, I. R. (2020). Response of a natural Antarctic phytoplankton assemblage to changes in temperature and salinity. Journal of Experimental Marine Biology and Ecology, 532: 151444.

Baliarsingh, S. K., Srichandan, S., Lotliker, A. A., Kumar, T. S., \& Sahu, K. C. (2018). Zooplankton distribution in coastal water off Gopalpur, north-western Bay of Bengal. Journal of Ocean University of China, 17(4): 879-889.

Bandara, K., Varpe, Ø., Wijewardene, L., Tverberg, V., \& Eiane, K. (2021). Two hundred years of zooplankton vertical migration research. Biological Reviews. 96: 1547-1589.

Christoffersen, K., Riemann, B., Klysner, A., \& Søndergaard, M. (1993). Potential role of fish predation and natural populations of zooplankton in structuring a plankton community in eutrophic lake water. Limnology and Oceanography, 38(3): 561-573.

D'Alelio, D., Libralato, S., Wyatt, T., \& d'Alcalà, M. R. (2016). Ecological-network models link diversity, structure and function in the plankton foodweb. Scientific Reports, 6(1): 1-13.

Davis, C. C. (1965). The marine and freshwater plankton. Michigan: Michigan State University Press, pp. 562.

Durant, J. M., Molinero, J. C., Ottersen, G., Reygondeau, G., Stige, L. C., \& Langangen, Ø. (2019). Contrasting effects of rising temperatures on trophic interactions in marine ecosystems. Scientific Reports, 9(1): 1-9.

Fernandes, V., \& Ramaiah, N. (2009). Mesozooplankton community in the Bay of Bengal (India): spatial variability during the summer monsoon. Aquatic Ecology, 43(4): 951-963.

Greenwood, A., O'Riordan, R. M., \& Barnes, D. K. A. (2001). Seasonality and vertical zonation of zooplankton in a semi-enclosed sea lough. Journal of 
the Marine Biological Association of the United Kingdom, 81(2): 213-220.

Ibáñez-Tejero, L., Ladah, L. B., Sánchez-Velasco, L., Barton, E. D., \& Filonov, A. (2018). Vertical distribution of zooplankton biomass during internal tidal forcing under mesoscale conditions of upwelling and relaxation. Continental Shelf Research, 171: 1-11.

Islam, A. K. M. N. and Aziz, A. (1975). A preliminary study of the zooplankton of north-eastern Bay of Bengal, Bangladesh. Bangladesh Journal of Zoology, 3(2): 125-138.

Jitlang, I., Pattarajinda, S., Mishra, A., \& Wongrat, L. (2007). Composition, abundance and distribution of zooplankton in the Bay of Bengal. In: The ecosystembased fishery management in the Bay of Bengal, Department of Fisheries, Thailand, Penang, Thailand, pp. 65-92.

Khondker, M. (ed.). 2008. Encyclopedia of flora and fauna of Bangladesh. Volume 2-4. Bangladesh Asiatic Society.

Kiørboe, T. (1997). Population regulation and role of mesozooplankton in shaping marine pelagic food webs. Hydrobiologia, 363(1): 13-27.

Mamun, M. M., Sarower, M. G., Ali, M. A., Rahman, S. M. B., \& Huq, K. A. (2009). Abundance and distribution of plankton in the Sundarbans mangrove forest. Journal of Innovation and Development Strategy, 3(3): 43-54.

Nandini, S., Merino-Ibarra, M., \& Sarma, S. S. S. (2008). Seasonal changes in the zooplankton abundances of the reservoir Valle de Bravo (State of Mexico, Mexico). Lake and Reservoir Management, 24(4): 321330.

Nowicki, C. J., Bunnell, D. B., Armenio, P. M., Warner, D. M., Vanderploeg, H. A., Cavaletto, J. F., Mayer, C. M.,
\& Adams, J. V. (2017). Biotic and abiotic factors influencing zooplankton vertical distribution in Lake Huron. Journal of Great Lakes Research, 43(6): 10441054.

Prabhahar, C., Saleshrani, K., \& Enbarasan, R. (2011). Studies on the ecology and distribution of zooplankton biomass in Kadalur coastal zone, Tamil Nadu, India. Current Botany, 2(3): 1-4.

Rakhesh, M., Raman, A. V., \& Sudarsan, D. (2006). Discriminating zooplankton assemblages in neritic and oceanic waters: A case for the northeast coast of India, Bay of Bengal. Marine Environmental Research, 61(1): 93-109.

Sailley, S. F., Polimene, L., Mitra, A., Atkinson, A., \& Allen, J. I. (2015). Impact of zooplankton food selectivity on plankton dynamics and nutrient cycling. Journal of Plankton Research, 37(3): 519-529.

Sharif, A. S. M., Islam, M., \& Bhuyan, S. (2017). Zooplankton in the lower Meghna River and its estuary with relation to physico-chemical parameters, Bangladesh. International Journal of Zoology Studies, 2(2): 06-15.

Srichandan, S., Panda, C. R., \& Rout, N. C. (2013). Seasonal distribution of zooplankton in Mahanadi estuary (Odisha), east coast of India: A taxonomical approach. International Journal of Zoological Research, 9(1): 17-31.

Tomas, C. R. (ed.). (1997). Identifying marine phytoplankton. Academic Press, San Diego.

Verheye, H. M., \& Hutchings, L. (1988). Horizontal and vertical distribution of zooplankton biomass in the southern Benguela, May 1983. South African Journal of Marine Science, 6(1): 255-265. 